\title{
Majorities and Minarets: Religious Freedom and Public Space
}

\section{DAVID MILLER ${ }^{1}$}

The paper examines the issues that are raised when democratic majorities take decisions that impose restrictions on religious minorities. Sometimes the problem can be avoided through 'the strategy of privatisation', but not when the issue is the character of public space. As a challenging case, the paper considers the Swiss referendum decision to ban any future construction of Islamic minarets. It examines two grounds on which such a decision could be opposed: the human right to freedom of religion, and the liberal principle of equal treatment of cultures. It argues that the human right does not extend so widely, and that the equal treatment principle can be trumped by considerations of national identity when public space is involved. Nevertheless the content of that identity, and its public expression, must remain open to democratic deliberation, and the Swiss decision to impose a constitutional ban on minaret-building can be faulted on those grounds.

\section{THE SWISS MINARET BAN}

In late November 2009, the Swiss voted in a national referendum to ban all future construction of Islamic minarets in their country. This decision drew widespread criticism both inside and outside Switzerland. It was regarded as a significant breach of liberal principles of freedom and equality, and as evidence of a wave of Islamophobia that was sweeping across Europe. ${ }^{2}$ Switzerland is unusual in the use it makes of different forms of popular referendum - this one was a 'federal initiative' that added a new clause to the Swiss constitution - to decide questions of law and policy that in other places are determined by

\footnotetext{
${ }^{1}$ Nuffield College, University of Oxford (email: David.miller@nuffield.ox.ac.uk). I should like to thank Alexander Kuehl and Mira Wolf-Bauwens for research which contributed to the writing of this paper. Earlier versions were presented as lectures at the following universities: McGill, Queen's (Ontario), Toronto, Pavia, Helsinki and Oxford, and I am grateful to all these audiences for their questions and comments on these occasions. I am especially thankful to the following for individual discussions and written comments: Joseph Carens, Emanuela Ceva, Marcus Haggrot, Sam Kiss, Cecile Laborde, Catherine Lu, Tariq Modood, Margaret Moore, Alan Patten, Lea Ypi, and three anonymous referees for this journal.

${ }^{2}$ For this interpretation, see for example Nussbaum 2012.
} 
representative institutions. ${ }^{3}$ The proposal won the approval of $57.5 \%$ of those who voted, and gained majority support in 22 out of 26 cantons. Thus it appears to present a clear case in which the will of a democratic majority came into collision with the rights of a religious minority, here the rights of Swiss Muslims to build mosques with minarets or to add minarets to existing buildings. And so it raises some fundamental questions of political philosophy: the general issue of majority will versus minority rights, but also the more specific issue of a historic nation's right to preserve features of its cultural inheritance in the face of demands for equal treatment by incoming minorities. Thus the Swiss minarets decision raises questions for those like myself who want to defend a liberal form of nationalism. Can national self-determination and liberalism be coherently combined, or must one of these ideas give way to the other in hard cases such as this?

This paper looks closely at the issues raised by the minarets ban, exploring both the arguments that were used, or might have been used, to support it, and the arguments that were brought, or might have been brought, on the other side. It takes both sets of arguments seriously. In doing so, it sets aside the possibility that the minarets initiative was merely a pretext for certain political actors, most notably the Swiss People's Party, to win support by riding on a wave of hostility to Islam. There is no question that the campaign for the initiative contained Islamophobic elements, not least the rather lurid poster that showed the Swiss flag festooned with black minarets looking rather like bayonets with a burka-clad woman standing in front of it. Yet in politics defensible positions, whether of the right or of the left, can always be supported by individual persons for indefensible reasons,

\footnotetext{
${ }^{3}$ Hereafter I shall use 'referendum' as the term commonly used to describe popular votes of this kind, though the Swiss themselves use the term in a more restricted and technical sense.
} 
and it would be reductive to suppose that any political decision that burdens Muslims at the expense of other citizens, as this one did, must be dismissed as stemming merely from religious prejudice. By treating the referendum as merely an opportunity for those opposed to Islam to show their distaste, one can avoid confronting the real issues about identity and control over public space that the Swiss debate over minarets raises. Moreover there is a danger of applying double standards here. In early 2013 the Swiss again voted in a referendum, this time to widespread liberal applause, on a proposal to curb executives' pay and bonuses and to outlaw 'golden parachutes'. No doubt some of those who supported this proposal were motivated by envy and resentment rather than principled considerations; yet this should not cause us to discount the arguments of social justice that were used to defend it.

The particular feature of the minarets decision that sets it apart from other measures that affect the rights and interests of religious minorities is that it concerns the character of public space. It is generally recognized that decisions that burden such groups stand in need of special justification, since they may force a religious minority to abandon some practice or mode of behaviour that they regard as central to their identity, whether this is a matter of a style of dress, the use of time set aside for religious ceremonies, or particular forms of religious expression. In many cases, it is possible to circumvent the problem by employing what has been called 'the strategy of privatisation' together with 'the rule-and-exemption approach' (which is often the solution favoured by liberals). ${ }^{4}$ Typically the problem is whether to grant exemption on religious grounds to laws that otherwise are general in scope. Thus a majority might support laws that regulate animal slaughter, and the issue

\footnotetext{
${ }^{4}$ These terms are taken from Barry 2001, ch. 2.
} 
would be whether to give religious minorities special dispensation to kill animals in ways that produce halal or kosher meat. Or the question might be whether to allow believers to wear religious symbols in defiance of general rules that lay down a dress code for workplaces or schools. In these cases, a majority may simply legislate to impose a uniform rule on all citizens, but it also has the option of privatising the issue by granting exemptions to designated minorities who can show that complying with the rule would severely burden them by requiring them to act against their consciences or prevent them from engaging in important symbolic practices. Whether such a rule-and-exemption approach is defensible in any particular case will of course raise issues of justice and equality. ${ }^{5}$ But wherever we think that the balance should be struck between majority will and minority rights in such cases, the option of privatisation, where the majority agrees to do one thing but allows the minority to go its own way, is always on the table.

This is not so, however, in cases where what is at stake is essentially some feature of public space that all parties will have to share. Here either the majority must decide on the basis of its own preferences or convictions, or it must defer to the minority. Suppose the question is what flag should fly above the city hall. While sometimes a compromise may be possible - different flags might fly on alternate days - what is not possible is for the majority view to prevail while granting an exemption to the minority. Everyone has to walk past the flag whatever design is chosen.

\footnotetext{
${ }^{5}$ See the powerfully argued critique of the approach in Barry 2001, ch. 2. For responses to Barry, see Kelly 2002.
} 
The Swiss minarets decision, by virtue of its national scope and the vigorous political campaign that preceded it, was a particularly striking example of a dispute over the place of religious symbols in public space, but it reflected a wider set of arguments in European countries about the construction of mosques, their siting, architecture and so forth. ${ }^{6}$ Very often proposals to build mosques have been opposed by groups of citizens who are concerned about what they see as the likely impact of the mosque on the character of the surrounding community. Some of these objections are practical, having to do with increases in traffic, for example, but in many cases the underlying concern is with the symbolic character of public space. Minarets, their shape and size, are often a major source of dispute. A minaret is seen by its opponents as a sign of cultural domination, as will shortly become apparent in the Swiss case, and resisted on that basis. As one commentator puts it, 'the minaret appears to have become a symbol par excellence of the conflict surrounding Islam, or rather of its visibility in the public eye - even more than the hijab, for example' ${ }^{7}$ In a number of cases, resistance to a perceived threat of domination has been shown by local authorities restricting the height of minarets, sometimes ruling that they must remain lower than nearby churches or cathedrals. It is hard to make sense of this concern about the relative height of a spire unless one understands the underlying issue to be one about which culture, if any, should be given dominant expression in the architecture of public space. Is it justifiable to privilege the culture of the indigenous majority by confining incoming minority cultures, such as that of Islam, to a subordinate position; or must a policy of strict cultural

\footnotetext{
${ }^{6}$ See the valuable survey in Allievi 2009.

${ }^{7}$ Allievi 2009, 45.
} 
neutrality be followed? This is a question that requires a political decision, whether at state or at local level.

In the Swiss case, the referendum on minarets came about as a result of a dispute in a small town called Wangen bei Olten in which an application by the Olten Turkish Cultural association to add a small minaret to its clubhouse met with opposition and was refused by the local building and planning commission. Their decision was overturned by the cantonal Building and Justice Department, provoking a legal battle that ended when the Federal Supreme Court ruled that the minaret could be built. This provoked the right-wing Swiss People's Party to gather the 100,000 votes needed for a referendum on a federal initiative whose effect would be to amend article 72 of the Swiss constitution by adding a simple, stark clause: 'Der Bau von Minaretten ist verboten'. The Swiss government, which was opposed to the ban, and believed on the basis of prior polling data that it would be defeated, nevertheless accepted the outcome of the referendum. Outside of Switzerland it met with widespread condemnation, not only among Muslims, but among liberal commentators, and even the Vatican, which described it as 'a blow to religious freedom'. It was confidently predicted that the decision would be overturned through an appeal to the European Court of Human Rights, but so far at least this has not happened. Swiss Muslim groups have attempted to bring such an appeal, but their lawsuits were turned down as inadmissible on the grounds that they could not show that they were 'victims' in the relevant sense, since according to the court the ban had had no practical effect on their exercise of their human rights. The current position, therefore, is that no more minarets can be built on Swiss soil to add to the four that already exist. 
What arguments were offered in the course of the campaign leading up to the referendum? The central claim of proponents of the ban was that minarets are signs of Muslim power and territorial advancement. As one put it, they should be seen as 'spearheads of political Islamisation'. ${ }^{8}$ Another compared them to 'the flags that generals place on strategic military maps to identify a conquered territory'. ${ }^{9}$ Allowing minarets to be built would also lead to further demands, for example for the muezzin's call to prayer to be permitted, and for the introduction of Sharia law. It was further claimed that minarets were not essential to the practice of Islam itself. According to an initiative committee press release:

Millions of Muslims worldwide practice their faith in mosques without minarets. The minaret is mentioned nowhere in the Quran. It has no religious function. No Muslim is affected in his free exercise of religion if minarets are not built. ${ }^{10}$

Supporters of the ban rejected claims that minarets and church steeples should be treated alike, on the grounds that 'the church tower is an expression of our Christian-western cultural inheritance'; furthermore the modern Christian church, in contrast to Islam, recognized the separation of church and state. ${ }^{11}$ The implication was that the building of a minaret was a political act in a way in which the construction of a church spire would not be. Moreover the wish to build minarets was a sign that Muslims were unwilling properly to integrate into Swiss society. Finally, a women's group 'against the Islamisation of

\footnotetext{
${ }^{8}$ Reimann (2009).

${ }^{9}$ Oskar Freysinger, cited in Green 2010, 637.

${ }^{10}$ Green 2010, 636.

${ }^{11}$ Freudiger ND.
} 
Switzerland' claimed that support for the ban meant support for rights to freedom and equality for all women living in Switzerland.

Opponents of the ban mounted a range of arguments, including feminists within the main parties who claimed that the effect of the initiative would be to further isolate Muslim women from others in Switzerland. It was argued that minarets themselves were not the real issue; the campaign was being used as a way of stirring up hostility to Islam in general. Rather than encouraging the integration of Muslims into Swiss society, the ban would have precisely the opposite effect. Such an initiative endangered religious peace and religious tolerance, and by singling out the symbol of one particular religion for prohibition, it violated the principle of equal treatment of religions. It was further argued that existing legislation gave local authorities adequate powers to regulate all building proposals, including minarets, so imposing a blanket ban was completely unnecessary to avoid any problems that building a minaret in a particular place might pose.

Although these substantive claims on either side formed the heart of the debate, the second-order issue of what was and was not a proper subject for democratic decision occasionally surfaced. Thus opponents of the ban argued that it was contrary to international law, and would be overturned by the European Court of Human Rights, provoking supporters to claim that the initiative itself was a beacon of Swiss sovereignty and Swiss democracy, to be contrasted with the undemocratic character of international law. After the ban was passed, questions were raised about the prerogative of the Swiss parliament to declare initiatives invalid if they violated 'peremptory' norms of international law. It was suggested that the federal chancellery might be better placed to perform this function instead. 


\section{THE RIGHT TO RELIGIOUS FREEDOM}

The central question of political philosophy raised by the minarets ban concerns the scope and limits of democratic decision-making. When does a decision taken by a democratic majority overstep the bounds set by fundamental liberal principles? I assume here that in a liberal democracy, some policies that might attract majority support should nonetheless not be enacted. The clearest example would be policies that infringe the human rights of a minority of citizens. But one can go further: majority decisions must comply with the principle of equal treatment of all citizens even when human rights are not at stake. Of course this does not mean that in the case of any particular decision there cannot be winners and losers. Our question, then, is under what conditions a majority can justifiably take a decision that burdens a minority group without breaching the underlying principle of equal citizenship. Since the ban on minaret construction undoubtedly represents such a burden - a form of religious expression that many Muslims would value has been prohibited - it provides a clear-cut example of the wider question.

The minaret ban also, however, raises a more specific question that I want to set aside for the time being and return to later in the discussion: was a constitutional amendment covering the whole of Switzerland an appropriate way for those opposed to minarets to pursue their objective - as opposed, for example, to more routine legislative referenda held in individual cantons ? $^{12}$ Here the question is where the line should be drawn between

\footnotetext{
${ }^{12}$ Even at federal level, there are a number of different referendum formats that can be used: see Linder 2010, ch. 3.
} 
decisions that are taken by normal democratic means, and accordingly subject to revision by the same means at some later date if the political community changes its mind, and decisions that are properly constitutional in nature, i.e. intended to bind democratic majorities by laying down principles that will constrain their future decisions. It is one thing to say that a demos is permitted to vote for a ban on the building of minarets, and another to say that its decision should be or may be constitutionally entrenched. To bracket off this further issue, I propose to focus on the more basic case where a democratic majority decides not to allow the building of minarets in the area under its jurisdiction, but without denigrating Muslims or restricting their freedom in other ways. It does so because it wishes the area to retain its traditional character, which includes the prominence of church spires and other features that reflect its western-Christian past. Why might such a decision be open to objection?

There are two main grounds on which such a decision might be challenged. First, we can ask whether policies such as a minaret ban infringe the human rights of those whose religious freedom is restricted. Second, we can ask whether a restriction that applies only to the symbols or practice of one religion but not to those of others unjustifiably violates a liberal principle of equal treatment or neutrality. ${ }^{13}$ Human rights and equal treatment cannot always be kept separate because of the existence of a human right against discrimination. But in the present case they can. In the first instance we are asking about a restriction on religious freedom, and our question will be about the scope of the right of religious expression: does religious free expression extend to the right to construct religious

\footnotetext{
${ }^{13}$ What 'neutrality' means is a much-debated topic in liberal political theory. For present purposes, the relevant sense of state neutrality is 'neutrality of treatment' as explained and defended by Patten 2012.
} 
buildings of a particular type? In the second instance the question is about the scope of the principle of equal treatment of religions, or alternatively about the grounds on which it may be justifiable to privilege one religion over another when public space is at stake.

Responding to religious claims selectively might be objectionable even in cases where there is no basic right to the form of expression that is being asked for.

The basis for an objection on human rights grounds might begin with the charter provisions that protect religious freedom. ${ }^{14}$ Thus Article 18 of the International Covenant on Civil and Political Rights contains the following clause:

1. Everyone shall have the right to freedom of thought, conscience and religion. This right shall include freedom to have or to adopt a religion or belief of his choice, and freedom, either individually or in community with others and in public or private, to manifest his religion or belief in worship, observance, practice and teaching.

There is also, however, a rider that sets out the grounds on which this freedom can be restricted:

3. Freedom to manifest one's religion or beliefs may be subject only to such limitations as are prescribed by law and are necessary to protect public safety, order, health, or morals or the fundamental rights and freedoms of others. ${ }^{15}$

\footnotetext{
${ }^{14}$ I do not treat official human rights documents as having canonical status for the understanding of human rights, but they may as in the present case provide a useful starting point for philosophical reflection and interpretation.

${ }^{15}$ Brownlie \& Goodwin-Gill 2006, 364.
} 
Very similar wordings can be found in Article 9 of the European Convention on Human Rights.

How might these human rights provisions apply to the minarets case? Let me deal first with what appears to be the more straightforward issue, namely whether the reasons presented by those opposed to the building of minarets correspond to any of the limitations referred to in Article 18.3. It seems clear that they do not. Supporters of the ban point to the general social and cultural consequences that they claim would follow if minarets were permitted to be built. But they do not suggest that minarets pose a risk to public safety, order, health, or morals and it is difficult to see how even a prima facie plausible case along these lines could be made. When practical objections to minarets are raised, they refer to the possible nuisance value of these edifices to those living in the surrounding area, and especially to the risk that they might in future be used for the call to prayer. But this cannot be construed as affecting the fundamental rights and freedoms of others. Now one should note here that in practice courts, including the European Court, have allowed a wider set of considerations to limit the exercise of human rights, including the right to freedom of religion; in other words, they interpret 'the rights and freedoms of others' more generously such that nuisance value might qualify as a rights-violation. ${ }^{16}$ On a more rigorous interpretations of human rights (which I favour), however, it is very hard to see that one could restrict the right to build minarets by appealing to the human rights of non-Muslims affected by their presence.

\footnotetext{
${ }^{16}$ Evans 2001, ch. 7, esp. 160-4.
} 
So the question then becomes whether a positive defence of such a right could be mounted by reference to Article 18.1 which sets out the right to freedom of religion. It is clear from the wording of the clause that it is intended to cover more than just the right to hold religious convictions in private, or to express them in the space of one's home. The Article refers explicitly to the manifestation of religious belief 'in community with others' and 'in public'. On the other hand, it refers only to 'worship, observance, practice and teaching' and says nothing directly about the physical environment within which these activities are going to occur. It does not say that there is a human right to erect buildings of a distinctive type within which to carry out worship, observance, and so forth. So we are not being given explicit guidance on whether the human right will include the right to erect minarets, or more generally to construct churches, synagogues and other buildings within which to practise one's religion.

The answer to our question may, however, seem obvious. The freedom of religion clause is understandably general in nature, and should not be expected to descend to matters of detail such as religious buildings. But insofar as the intention of the clause is to protect the public practice of religion, by implication it also protects the creation of physical sites within which that practice is carried out. If a church congregation is going to exist, it needs a church inside which to gather, complete with altar and so forth, and similarly for the other faiths. Such an extension of the right seems hard to deny. ${ }^{17}$ But it rests on the thought that certain physical features are essential to the practice of the religion. And it therefore invites us to draw a distinction between features that are indeed essential, and others that

\footnotetext{
${ }^{17}$ For a discussion of the nature of such a right, concluding that it must be conceived as a collective rather than individual right, see Ceva \& Zuolo forthcoming.
} 
are merely desirable because, for example, they enhance the experience of worshippers in aesthetic or other ways. A church altar may be essential because of the role that it plays in the Mass or Communion service, but having stained glass windows in a church should be seen simply as a desirable addition because of the way in which it creates a special aura of sanctity within the building.

Can such a distinction be drawn, and should it be? Let me take the questions in reverse order, since if we shouldn't draw a distinction between what's essential to religious practice and what's merely desirable, we won't need to get into the intricacies of how the line should be drawn. Recall that what is at stake here is the human right to religious freedom, and specifically religious expression. We are not yet dealing with the wider question of what a liberal principle of equality requires. Much will then depend on how one understands the purpose, and the justification, of human rights. This is a large topic, and I will assume a position that I have defended elsewhere, which is that the aim of human rights is to provide their bearers with the opportunity to lead a minimally decent life, by protecting them against threats imposed primarily by states, and by creating obligations for states and other institutions to provide the material conditions for such a life. ${ }^{18}$ On this understanding, the content of human rights should be construed in a minimalist way, in the sense that they should be understood to require only the least demanding means of securing the relevant opportunities. If the human right to shelter can be satisfied by building either type A houses or type B houses, and type A houses are cheaper to build, then a state that builds sufficient

\footnotetext{
${ }^{18}$ Miller 2012a; Miller forthcoming.
} 
type $A$ houses has discharged its human rights obligations even if many people would prefer to live in houses of type B.

Since having the opportunity for a minimally decent life does require having the right to religious worship and observance, there can be no objection, on the view I defend, to including this right in the human rights catalogue. But equally it must be understood to extend only to what is essential to religious practice, the equivalent of a type A house. So we how can we tell what is essential and what is not? There are broadly two ways of approaching this question. ${ }^{19}$ One is to regard it as a matter of individual conviction. So long as the individual believer sincerely holds that the practice of his religion demands a particular form of physical expression, that form is taken to be essential. Debates in the U.S. about freedom of religious expression have tended to move in this direction. ${ }^{20}$ In contrast, European approaches to religious freedom, including decisions taken in the European Court, have adopted a more objective approach, applying a test of necessity to determine whether a particular activity is or is not required by the religion in question. This may involve consulting relevant texts, or obtaining expert evidence from religious leaders. There are certainly difficulties with this second approach, particularly the difficulty posed by dissenting

\footnotetext{
${ }^{19}$ There is a carefully nuanced discussion of this issue in Eisenberg 2009, ch. 5.

${ }^{20}$ Indeed rather than trying to distinguish between what is essential and what is not, American constitutional doctrine asks whether a government measure imposes a 'substantial burden' on religious exercise, and assesses this primarily from the perspective of the individual practitioner: see Greenawalt 2006, ch. 13. Thus some aspect of religious practice that matters a great deal to the individual in question will qualify even if religious authorities do not require it. Greenawalt defends this focus, but notes that it cannot apply in the same way 'when claimants ask for an action that would be reasonable only if it affects a larger group' such as preserving a sacred forest (207).
} 
minorities within mainstream religions. As a student of the European Commission of Human Rights points out, 'when there is disagreement between various members of a religion or belief over issues of doctrine and practice, the desire of the Commission to find an objective and authoritative answer to whether the practice is required can lead it to decide between competing approaches, sometimes rejecting an applicant's claim because it is outside the mainstream of his or her religion' ${ }^{21}$ For the objective approach to be properly applied, therefore, care must be taken to establish what the practice of any particular religious sect or tradition requires, regardless of whether others of the same general persuasion agree. Despite this difficulty, there are good reasons to prefer such an approach. When someone demands the right to engage in a particular mode of conduct on religious grounds, they are saying that this is something that they are compelled to do by their faith. This may be a case of inner compulsion, or of compulsion that arises from fear of being shamed by fellow-believers (or a mixture of both), but in any case it must stem from the belief that some authoritative body of doctrine requires it. It is this that gives claims that derive from religion their special force and distinguishes them from what we might call mere 'lifestyle' claims. ${ }^{22}$ But one cannot recognize this while holding that interpretation of religious doctrine is a wholly subjective matter. At any particular time, and within any particular religious faction, there must be a large measure of agreement on doctrine, even if

\footnotetext{
${ }^{21}$ Evans 2001, 123.

${ }^{22}$ It is important to keep in mind here that the question being addressed is about the human right to freedom of expression. It is not about the wider limits to expression that a liberal principle such as Mill's famous principle of liberty would set. On the view of human rights I defend, the question we should be asking is 'how much freedom of expression is essential for a person to lead a decent human life' not 'how much freedom of expression should a liberal state ideally allow'.
} 
there is dispute over certain requirements. There can be debates about whether courts in particular are well placed to reach valid conclusions about what is or is not an essential component of religious practice, ${ }^{23}$ but there must in general be a right or wrong answer to questions of this kind.

If we turn to the particular case of minarets, I know of no case where a court has been asked to rule on whether it is an essential feature of an Islamic mosque that it should have one. But were a court to be asked, it is likely that it would conclude that it was not essential. Relatively few mosques in European societies currently have them, and this is not just because applications to build them have been refused. ${ }^{24}$ Historically, it appears that associating a tower with a mosque did not become widespread until the $9^{\text {th }}$ century, and the building of minarets at that time had more to do with their functions as symbols of religious power than with their role in Islamic religious practice; they were not, for example, regarded as essential for broadcasting the call to prayer. ${ }^{25}$ To that extent, opponents who argue that minaret building has a symbolic purpose as an expression of power rather than a strictly religious function appear to have a point. The Ottoman style of minaret that was caricatured in the provocative pro-ban poster has only fairly recently spread as a recognizable Islamic symbol to regions of the world in which previously mosques were built without towers. ${ }^{26}$

\footnotetext{
${ }^{23}$ See Ahdar \& Leigh 2005; c.f. Eisenberg 2009, ch. 5.

${ }^{24}$ Allievi $(2009,46-47)$ notes that where such applications have been refused, local Muslims have often accepted the outcome, sometimes choosing instead to depict a minaret on the entrance door of the mosque.

${ }^{25}$ See Bloom 1989, chs. 4-5.

${ }^{26}$ Bloom 1989, 190-91.
} 
So although, for Muslims, the right to religious freedom must include the right to have access to a mosque - to build one, or to convert an existing building, if necessary - the features that are essential to a mosque are those that allow collective prayer and other rituals to be performed, and a minaret does not qualify for that purpose. What a minaret does, plainly, is to signal to the wider world that the building it is attached to is a mosque, increase its visibility, and in certain cases make it easier to broadcast the call to prayer. These may all be seen as desirable features, but they fall into the same broad category as stained glass windows, or indeed church spires, which are equally not essential to Christian practice. So although minarets cannot be objected to on human rights grounds, as I argued earlier, neither can they be defended on human rights grounds. The right to religious freedom does not cover them. So the first objection to a democratic ban on minarets fails. If such a ban is wrong, it is not because it violates the human rights of Muslims.

\section{EQUAL TREATMENT AND PUBLIC SPACE}

We should turn, therefore, to the second possible reason for objection that I outlined, namely that a ban would breach a liberal principle of equal treatment of religions, or of state neutrality. Clearly a minaret ban is directed against the practitioners of one particular religion, namely Islam. It makes no pretense of equal treatment; indeed supporters, as we have seen, argue quite openly that it is legitimate in countries like Switzerland to give favourable treatment to the historically-established religion, namely Christianity. So the issue we have to address is whether the equality principle extends to forms of religious expression such as minaret-building, and whether, therefore, it should be regarded as a constraint on democratic decisions over the use of public space. 
I will take for granted without discussion here the principle that the citizens of a liberal state should receive equal treatment with respect to their rights and opportunities, and bracket off the complications that may arise when some denizens of a liberal state do not qualify for citizenship. The relevant point for what follows is that the reasons behind the principle of equal rights also require the state to treat citizens equally when it comes to providing the resources that they need to pursue their individual or collective life projects. Very often this will take the form of providing, or subsidizing the provision of, public goods. So when the state contributes towards sports grounds, or art museums, or national parks, it should do so with the general aim of giving all citizens access to goods that they value, and value to approximately the same extent overall. Specifying a formal rule that captures this intuition is quite tricky, ${ }^{27}$ but for present purposes all we need is the broad claim that a state that provides hockey pitches but not baseball grounds at public expense in a society that includes significant numbers of people wishing to play either sport is behaving unjustly, and so equally is a state that subsidizes one form of music but not another, unless it can be shown that there is a special reason (of the right kind) why the preferred form won't survive without subsidy.

Applying this principle to the case of religions, it appears that if there is reason to support one religion, for example by granting a church charitable status for purposes of taxation, the

\footnotetext{
${ }^{27}$ I have attempted to do this in Miller 2004. There I defend the principle of equal net benefit - the state should endeavour to supply a package of public goods in such a way that each citizen benefits to the same extent compared to a baseline in which no goods are supplied, while conceding that the principle may not be fully realisable in practice, and also that it may not be appropriate for all classes of public goods.
} 
same must apply to all religions, again in the absence of special factors. So the equality principle holds here too. But now we encounter a difficulty. The argument for equal treatment goes through when there is no conflict involved in supplying different public goods, other than over the resources that are needed to produce the goods. So long as a local authority has sufficient space and resources, it can build a baseball stadium alongside a hockey field, and the presence of one does not detract from the value of the other. But this appears not to be the case in the disputes over public space that led to the Swiss minaret ban. Here it seems that the goods are to some extent rival. At least in the eyes of those who argued in favour of the ban, the building of a minaret in a particular location alters the character of the surrounding public space and diminishes its value for those who do not subscribe to Islam. We can see this rivalry occurring particularly clearly in cases where the dispute turns partly on the height of the proposed minaret in relation to nearby churches.

Now it might seem absurd for people to care about whether a minaret is 55 or 65 metres high - I shall address this issue shortly. But supposing that they do, it seems that the equal treatment principle is in trouble. Either the public architecture of a particular town or city will reflect its predominantly Christian heritage, with the church spire looming over the surrounding streets, giving those who value this heritage what they want, or the erection of a minaret makes a statement about the increasing public prominence of Islam, a good presumably for local Muslims. So what could equal treatment mean here? The state might try to rid public space of all culturally laden symbols, which would presumably mean demolishing church spires and other Christian artefacts as well as banning the construction of minarets. But this would mean pursuing equality at the expense of giving any of the rival groups the public goods that it sought, a form of cultural as well as physical levelling down. 
A more plausible suggestion is that it should regulate public space only through the application of neutral building regulations, zoning laws, etc., and then allow the market to decide what actually gets built. It would be irrelevant whether what was being proposed was a church, a mosque or a supermarket; the only relevant considerations governing the decision would be culturally neutral factors such as safety, noise, congestion and so forth.

The problem with this suggestion is that by disaggregating decisions about the use of space and allowing the market to rule, it denies that there is any collective interest in the way that cities, towns and villages look in general. Yet plainly this is something that people care about a great deal. They want the places they live in and are attached to to look both beautiful and familiar, and this means that when new buildings are planned it is legitimate to ask what effect their presence will have on the local environment. So far this is just an aesthetic matter. But it shows that there is a good case for subjecting what is built in public space to democratic control. People should be able to decide how tightly or loosely they want new buildings to match what already exists, and this is no doubt going to depend on the character of the status quo ante. What is acceptable in a stone-built village will be very different from what will work in a city landscape that is already a jumble of architectural flights of fancy. Nonetheless having public space that reflects the aesthetic preferences of the people who occupy it is a public good, and accordingly something that justifies democratic oversight rather than leaving everything to private initiative and the market.

A question that might be asked here is how this argument for democratic control can distinguish between public buildings, such as mosques with minarets, and the external aspect of private buildings. For example, someone might wish to decorate the outside of their house in a particular way to celebrate a religious festival, and since this decoration will 
be visible to passers-by, it will according to the principles I am defending be potentially subject to a democratic veto; and this seems to open the door to intolerance. Now the design of private buildings is already governed by planning law in most jurisdictions, so the baseline here is not complete freedom to do whatever the owner wishes with her private property. The key question is whether a form of decoration changes the appearance of the building in a fundamental way, and this is a matter both of the scale of the change and whether it is permanent or temporary. If the change is fundamental and clearly visible to outsiders, then it falls within the scope of democratic decision. Admittedly, some judgement is involved here: one may ask whether in a particular case it is reasonable to regard what someone is doing with their private property as having a significant external impact, and it will be a feature of a tolerant society that it permits owners a good deal of freedom. ${ }^{28}$ A minaret, however, is by its nature both a permanent and a prominent feature of the neighbourhood it occupies, and so a proposal to build one is clearly a proper subject for democratic debate if the reasoning laid out above is accepted.

The argument up to this point is essentially about the physical appearance of buildings, and what it suggests in relation to mosques and minarets is simply that they should be built in a style that harmonises sufficiently with existing town- or cityscapes, that if there is a

\footnotetext{
${ }^{28}$ An interesting case to ponder here is Syndicat Northcrest v. Amselem in which five Jewish occupants of an apartment building in Montreal claimed the right to erect succahs on their balconies for the nine days of the festival of Sukkot, in defiance of their co-ownership agreement which prohibited any edifices being built on balconies. The majority on the Canadian Supreme Court, finding in favour the five, argued that the aesthetic and property-value objections to such temporary structures were not sufficient to outweigh the religious rights of the tenants. For a discussion of the case, see Eisenberg 2009, ch. 5.
} 
particularly fine view of the local cathedral, a minaret shouldn't be sited just where it blocks that view, and so forth - nothing has been said so far about their religious significance. In order to produce even a prima facie case for banning minarets as Islamic symbols, we would need to make the much stronger assertion that a majority is entitled to ensure that the appearance of public space reflects its own cultural values, so that where those values reflect a Christian heritage, it can insist that Christian buildings and symbols should remain hegemonic. This means explicitly setting aside the equal treatment principle in the case of contested public space. Instead the claim must be that the state is not required to remain neutral when what is at issue is the culture of the indigenous majority. What could justify this?

\section{NATIONAL IDENTITY AND RELIGIOUS PRECEDENCE}

A positive answer to this question will rely upon a certain background picture of historic nations, the territory they (legitimately) occupy, and their relationship to incoming minority groups who intend to build a life in that territory. This picture will undoubtedly be controversial, but without it we cannot make sense of the beliefs and attitudes that lie behind the minarets dispute. I have elaborated this picture elsewhere and will here provide just a bare outline. ${ }^{29}$ When a people with a distinctive national culture occupy territory over time and transform it to meet their needs, they acquire the right to preserve and enjoy the value they have thereby created. Part of that value is material, but another part is symbolic, as the territory comes to bear the imprint of the national culture. So on the one hand, the nation becomes a candidate for territorial rights, especially rights of jurisdiction, which can

\footnotetext{
${ }^{29}$ See Miller 1995; Miller 1997, ch. 8; Miller 2008.
} 
be exercised when political institutions that represent it are established. ${ }^{30}$ On the other hand, the physical shape of the territory is likely to serve as one of the principal media through which the public culture of the group is reproduced over time. Clearly it is not the only medium: the group's culture will also be conveyed through the practices of everyday life, through books and other cultural artefacts and so forth. But the physical environment, including the built environment, will be an important repository of culture. In a sense, then, members of the national majority come to understand their own historic identity partly through their direct experience of the environment they and their predecessors have created. As they look around, they will see public space that is replete with cultural symbols: statues of national leaders, historic monuments, war memorials, etc. In cases where a particular religion has played the dominant role in national life, this will extend to churches, temples, mosques and so forth. So the value that is created by preserving this heritage is the value of national identity itself.

Whether national identity has such a value is of course a disputed question. Its defenders argue that it serves important political aims, helping to stabilise democracy and to promote social justice. ${ }^{31}$ Critics argue that these functions can be performed in other ways, for example by citizens displaying loyalty to a common set of institutions and to the principles that lie behind them (as in so-called 'constitutional patriotism'). ${ }^{32}$ In the absence of realworld examples of successfully functioning societies that are held together by nothing more than political bonds of the latter kind, as opposed to the thicker bonds of common culture,

\footnotetext{
${ }^{30}$ I have defended this position in Miller 2012b.

${ }^{31}$ See e.g. Canovan 1996, ch. 4; Miller 1995, chs. 3-4; Tamir 1993, chs. 5-6.

32 See e.g. Abizadeh 2002; Habermas 1998, ch. 4; Mason 2000, ch. 5; Weinstock 2001.
} 
this dispute is hard to resolve. ${ }^{33}$ Whether or not national identities have the instrumental value that their supporters claim ${ }^{34}$, however, it is clear that many people have a strong subjective interest in retaining them, and therefore in preserving the means by which they are reproduced over time. This includes, as suggested above, retaining control over the symbolic character of national territory.

A further element of control, which forms part of the package of territorial rights, is the right to control immigration and to make permanent admission to the territory conditional on meeting certain requirements. On being admitted, immigrants acquire both rights and obligations that they previously lacked. It is helpful here to think in terms of a 'quasicontract' whereby immigrants are granted a bundle of rights and opportunities, including the opportunity to advance in time to full citizenship, and in return are asked to accept certain obligations to integrate with the host society. ${ }^{35}$ In many domains, they can claim to be treated equally with existing citizens, and this includes claims that reflect their distinctive cultures. Thus if the state is already involved in subsidising certain types of music or dance, immigrants group can ask for similar subsidies for the new forms they bring with them; or if they play sports that are not currently represented, they can make proportional claims for resources to support these. They cannot however expect to be able to reproduce the

\footnotetext{
${ }^{33}$ Some authors have taken Switzerland to be an example of a state unified entirely by its institutional mechanisms and accompanying political traditions. But a closer look at Swiss history reveals the importance of an emerging national identity, at least in the period since 1848. See the symposium on this topic in Nations and Nationalism, 17(4), 2011, and especially Wimmer 2011.

${ }^{34}$ We have explored some of the evidence, and the difficulties it presents, in Miller and Ali forthcoming. ${ }^{35}$ Miller 2008. A rather similar idea lies behind Kymlicka's concept of 'fair terms of integration': see Kymlicka 2001, ch. 8 .
} 
inclusive 'societal culture' (to use Kymlicka's phrase) of the place they have left ${ }^{36}$ They have joined a society with an existing public culture, and although they can reasonably expect that the culture will over time adjust in ways that recognize their presence, for the moment they must acknowledge its precedence in some domains. For example, they must recognize the legitimacy of the prevailing political institutions - those of a constitutional monarchy, say - whatever their personal convictions may be. Or they must respect the established pattern of public holidays even if this is not particularly to their liking. They remain at perfect liberty to argue for change, in private and in public, but until change occurs, the contract of integration they have implicitly signed entails that they must respect the practices and institutions that the public culture of the indigenous majority supports.

Once again, the background picture of immigrant rights and obligations just sketched is open to challenge. Those who believe in open borders and global freedom of movement will not accept that by joining a national society immigrants accept obligations over and above the universal obligation to respect the human rights of those they interact with. To challenge that alternative view would take us too far afield here. My concern is rather to explore the implications for religious freedom of the broad understanding of the respective claims of national majorities and immigrant groups set out in the paragraphs above. The problem arises because in many cases public cultures will bear the imprint of the religion that historically has been dominant in the nation in question. This may take institutional form if the country has an established church, or in some other way gives public recognition to one religion at the expense of others. Under these circumstances, the general obligation that immigrants bear to acknowledge and adapt to the public culture of the receiving

\footnotetext{
${ }^{36}$ Kymlicka 1995, ch. 5.
} 
society must include an obligation to acknowledge, for public purposes, the precedence of that religion. Clearly this does not mean that they must convert to the national religion, or give up their own beliefs and practices. As we saw earlier, there is a human right to freedom of religion that includes the right to associate for purposes of religious observance and the right to create buildings suitable for that purpose. Moreover, they have a claim on the basis of equal citizenship that their religious practices should be supported in the same way as other religions, for example by being given charitable status. So they must acknowledge and adapt only in the sense of recognizing that in matters of public culture, one religion may take precedence, for example where the state recognizes an established church, and allows its officials to participate in state ceremonies or other functions.

My claim is not that states must recognize religion in this way, but only that they are permitted to do so. ${ }^{37}$ A state may follow the example of the U.S. and entrench an establishment clause in its constitution that requires it to observe strict religious neutrality. But equally it may follow the example of Denmark, say, and have a national church which is granted certain privileges and to which most people formally belong. ${ }^{38}$ Which of these models is chosen will be a matter of historical contingency, though it is also a subject for democratic deliberation to which immigrants once they are citizens are fully entitled to

\footnotetext{
${ }^{37}$ See the careful discussion of this issue in Laborde 2013. Laborde shows convincingly that Rawlsian political liberalism cannot adjudicate between what she calls 'moderate separation' and 'moderate establishment'. She goes on to argue that the former is required on republican grounds; I disagree, but will not pursue the argument here.

${ }^{38}$ Although formal establishment is less common, the practical relation between church and state in other European countries is far closer to the second model than the first. See Klausen 2005, ch. 5.
} 
contribute. It may well be that in societies that are both liberal and multicultural, the resulting trend will be in the direction of disestablishment and full religious equality (though some members of minority religions may accept that the established religion should continue to enjoy de facto priority ${ }^{39}$ ). So acknowledging religious precedence does not mean actively supporting it, or assuming that it will always obtain.

\section{RELIGIOUS PRECEDENCE AND THE MINARETS BAN}

It may still be said that granting religious precedence, in any form, is incompatible with treating members of religious minorities as equal citizens. I will come back to this issue shortly. Before that I want to examine how the argument about religious precedence outlined above bears upon a proposal to ban minarets. It seems as though there is a significant gap between acknowledging that religious precedence is sometimes permissible and contemplating a ban on the religious symbols of a particular faith. First, a prohibition that affects only one religion seems more problematic than a privilege that might be granted to another. ${ }^{40}$ Second, precedence seems to be a matter of the relative prominence of different forms of religious expression; it does not seem to require that any form of religious expression should be removed altogether. Are these reasons sufficient to dismiss the minaret ban even if one is willing to concede that it may sometimes be permissible to discriminate between religions?

\footnotetext{
${ }^{39}$ They will do this if they fear that the consequence of disestablishment is to entrench radical secularism instead. For a defence of a pluralised version of religious establishment, see Modood 2009.

${ }^{40}$ I am grateful to Margaret Moore for pressing me on this point.
} 
By implementing a constitutional clause banning all future building of minarets, the Swiss government has removed a liberty that was previously available to all Swiss citizens, Muslim and non-Muslim alike, the liberty to attempt to build tall towers. Of course this liberty was not absolute, since planning regulations would apply to all proposals, and Zurich, for example, imposes a general height limit on new buildings. Nevertheless there was a presumption that a proposal to build would be accepted so long as it complied with such regulations. The loss of liberty that the ban imposes can be contrasted with enabling ways of showing precedence, such as state subsidies to preserve the buildings associated with one particular faith, or allowing public broadcasters to give airtime to the services of one religion but not others. Measures such as this might disadvantage the excluded groups in some ways, but they are not being prevented from doing anything that they could do before. How, then, can the general case for precedence be extended to justify libertylimiting restrictions?

It would be necessary to show that the exercise of the freedom that is being removed is in some way harmful to the adherents of the favoured religion, or more generally those who value retaining its precedence in public space. This might seem hard to do. Why does adding a minaret to a mosque pose a threat of the inherited Christian culture of the majority? It is not as if a church is demolished every time a minaret is built. If we examine the Swiss debate, however, we find a dissonance between the claims made by supporters of the minaret ban, and the intentions we can reasonably attribute to those who want to build minarets. As we saw, advocates of the initiative argued that the building of minarets was a means by which Islam as a whole staked its territorial claims, akin to the flags planted by successful generals in a war. This portrays public space as zero-sum: either it is entirely 
Western/Christian in character or it becomes dominated by Islam. Minaret builders, we may assume, would disavow any such aim. They would argue that minarets should take their place alongside church steeples and other buildings in shared, multicultural public space. It would be hard for them to deny that a minaret serves to symbolise the arrival and in some sense the legitimacy of Islam. But they would repudiate any intention to dominate or conquer the place where it is built. So here the two sides hold conflicting views of what is at stake in the minarets dispute.

To adjudicate between them, we need to ask in what circumstances the creation of a minaret might alter the character of public space in such a fundamental way that the inherited religious culture would no longer enjoy a privileged status. There seem to be two cases. One is where the minaret does become the dominant feature of the town- or cityscape by virtue of its size or height. As we saw, practical disputes over minaret-building often focus on this feature, comparing the scale of the minaret with neighbouring Christian buildings. The other is where the balance between the two religious cultures shifts significantly by virtue of the presence of the new building: if a village currently has just a single church, then the arrival of an equally prominent mosque puts the two religions on an equal footing as far as public space is concerned. But this would not apply to a larger town that already had half-a-dozen buildings of Christian provenance.

It therefore looks as though the argument from precedence can only justify selective restrictions on minaret-building, and not an outright ban. How might a supporter of the initiative respond? Perhaps she might say that only a full ban would provide a sufficient safeguard in the cases mentioned above; she might argue that local planning committees 
are not robust enough to turn down culturally damaging proposals. ${ }^{41}$ Or she might argue that there is potentially a collective action problem whereby a series of individual decisions that allow minarets to be built produce an unanticipated change in the character of public space across the land (recall the provocative poster that shows sinister-looking black minarets springing up nationwide). Readers will form their own view about the plausibility of such arguments. But without them the gap between precedence and ban seems impossible to bridge. It begins to look as though even a sympathetic reconstruction of the reasoning behind the minarets initiative, such as I have been trying to provide, will not serve to justify the initiative itself. I return to this question in the following section.

\section{EQUAL CITIZENSHIP, RELIGIOUS PRECEDENCE, AND REFERENDA}

Up to this point I have accepted the general argument for allowing the state to favour one religion over others, given the appropriate background circumstances, but questioned whether this would permit it to enact laws such as an outright ban on minarets. But many liberals would challenge the general argument, thereby completely pre-empting the discussion in the preceding section. Martha Nussbaum, for example, a vociferous critic of religious precedence, argues that it unavoidably 'subordinates' or 'marginalizes' those who do not belong to the established religion; it amounts to a public declaration that they are second-class citizens. ${ }^{42}$ This extends to purely symbolic forms of recognition, which she

\footnotetext{
${ }^{41}$ Or perhaps that the decisions of local committees would be routinely overturned by higher level judicial bodies, as happened in the case at Wangen bei Olten that provoked the minarets initiative.

${ }^{42}$ See Nussbaum 2008, Introduction. Nussbaum concedes, however, that in some European countries with 'few religious differences that inspire real passion' it may be acceptable to permit an established church to exist for historical reasons (13).
} 
claims convey a message to the minority groups that they do not properly belong to the nation in question. Citing the example of crucifixes displayed in Italian school classrooms, she says that 'some religious symbols, set up by government, threaten the equal standing of citizens in the public realm' ${ }^{43}$ The difficulty with such claims is that they involve imputing a meaning to symbolic acts that may or may not be intended by the actors and may or may not be understood in the relevant way by the recipients. Is the crucifix display an endorsement of Roman Catholicism as Nussbaum supposes or simply a traditional part of school architecture? Moreover any endorsement or support on the part of the state for cultural forms might be faulted in the same way for failing to display equal respect for all citizens. What if the French government decides to subsidise its film industry in order to promote French language films, or the British government chooses to distribute free copies of Shakespeare to children because it wants them to absorb some of the language and imagery of his plays? In either case immigrants with different cultural backgrounds might feel that their own cultures were not receiving equivalent endorsement. But would they have any reason to think that their status as equal citizens was being denied? What seems crucial to equal citizenship is first that everyone should have equal access to the bundle of liberties, rights and opportunities that together constitute the status of citizen, and second that if the state does engage in cultural promotion it does so for reasons that it can justify publicly, for example on the grounds that it is helping to promote national identity. As noted earlier, immigrant citizens can engage with and challenge these reasons, arguing that national identity needs to be revised or that there are better ways to promote it, but losing the argument is not grounds for saying that their equal status has been undermined.

\footnotetext{
${ }^{43}$ Nussbaum 2008, 18.
} 
Even if there is no direct contradiction between religious precedence and equal citizenship, it might still be argued that state recognition of one particular religion does as a matter of empirical fact engender negative attitudes towards religious minorities, especially immigrant minorities, that threatens their status as equal members of the society. Comparative studies of church-state regimes, however, do not appear to support this argument. Thus a three-way comparison between Britain, France and Germany reveals that Britain, with its established church, has in fact been the most willing to adopt policies that accommodate Muslims. ${ }^{44}$ In apparent contrast, a study that examines church-state regimes at cantonal level in Switzerland finds that in cantons that score highly on the religious support index, popular attitudes towards Muslims are more negative. ${ }^{45}$ However one needs to tread carefully here, given our focus on equal citizenship. The three issues addressed in this study were the number of Muslims in Switzerland, the right to wear an Islamic headscarf in public, and the right to build minarets. Only the second of these issues presents a challenge to equal citizenship (since the right to appear in public wearing the apparel of one's choice counts as a basic citizenship right) and responses on this question showed only a weak relationship to a canton's support of the (Protestant or Catholic) church. It should not come as a surprise, given the interpretation of the minarets debate presented here, that in places where church support plays a more prominent role in public culture, opposition to Islamic minarets should be stronger. But favouring immigration controls and opposing minaret building does not mean treating Muslims as less than equal citizens.

\footnotetext{
${ }^{44}$ Fetzer and Soper 2005

${ }^{45}$ Helbling and Traunmüller 2014.
} 
What matters is not the awarding of religious precedence to the country's historic faith or faiths, but how decisions relating to precedence are taken. And here again we find reasons to question the minaret ban, this time relating to the procedure that was used to decide the issue rather than the substance of the decision itself. The ban had two noteworthy features: it was imposed by national referendum, and it took the form of a constitutional amendment. Contrast this with a hypothetical case in which decisions on the building of minarets were taken by democratic deliberation (which in Switzerland might well culminate in local referenda) in cities or cantons. ${ }^{46}$ There would be two important differences. First, decisions would be taken on proposals to create towers of a specific shape and size in particular places, allowing negotiation to take place over the height of the minaret, and so forth, and also responding to the strength of local feeling about how important it was to preserve the existing character of the environment. Second, whatever decision was taken would not be set in stone; it could be reversed at some later time if the relevant local community changed its mind or its character. ${ }^{47}$ From the minority's point of view, there is a difference between feeling that you have lost the argument on this occasion, and feeling

\footnotetext{
${ }^{46}$ It would also be important that Muslim voices contributed to the deliberation. An additional problem for the actual Swiss case is that so few Muslims have citizenship status. In 2000 they constituted $4.3 \%$ of the resident population, but only just over one in ten had qualified for citizenship: see Dolezal, Helbling and Hutter 2010, 173-4. Unusually in Switzerland admission to citizenship is decided at municipal level, and there is evidence that candidates from Islamic countries such as Turkey and Kosovo are discriminated against: see Hainmueller and Hangartner 2013.

${ }^{47}$ Technically, of course, the minaret ban could be reversed by a new federal initiative, but given the fairly demanding requirements that have to be met for this to pass, it seems reasonable to assume that the ban will remain in place for a generation at least.
} 
that a decision has been reached that forever prevents you from returning to the table with a similar proposal. Insofar as talk of marginalization or subordination applies, it is surely to the case where a minority is barred by a constitutional rule from advancing its legitimate interests through democratic contestation.

So the Swiss way of deciding the minarets issue is certainly open to criticism, quite apart from the intolerant language and imagery used by the pro-ban lobby. It is hard to think of a good reason why there should be a single constitutional rule applying throughout Switzerland to all future minaret proposals. If there exists a national consensus that the quality of public space will be damaged for cultural reasons by minaret building, then this would be reflected in a series of local decisions; if instead some more multicultural city like Geneva (which voted against the ban) chose to approve a minaret, it is hard to argue that the citizens of Appenzell, some 300 kilometres and many Alps away, have a significant interest in opposing it. So the constitutional ban could be opposed on democratic as well as on liberal-egalitarian grounds; a principle of subsidiarity applies here.

\section{CONCLUSION}

I suggested at the outset that the fundamental issue raised by minarets referendum was the scope and limits of democratic decision-making in a liberal society. I looked at two reasons one might have for thinking that a majority has no right to consider imposing such a ban. One was that it would infringe the human rights of Muslims; the other is that would violate the principle that all citizens must be treated as equals. On closer inspection, neither of these gave sufficient grounds for thinking that a ban must be impermissible. I then examined the reasons that would be needed to justify prohibiting minarets, talking my cue from the arguments that were actually put forward by supporters of the initiative, but 
setting them in a broader philosophical framework. I suggested that the ultimate appeal must be to an historic nation's right to shape public space in a way that reflects its identity and to transmit that identity over time. This might include religious symbols and structures where these have played a constitutive part in the identity itself. Even granting that the state may in these circumstances legitimately give precedence to the artefacts of a particular religion when decisions about the use of public space are taken, however, there appears to be no good justification either for the substance of the ban, or for the form that the decision took. The very presence of a minaret does not, in general, mean that public space loses its predominantly Western/Christian character. And a nationwide constitutional amendment symbolically closes the door to future democratic deliberation, and forces all cantons and cities to follow the same rule, in defiance of Switzerland's long and admirable tradition of local autonomy.

\section{References}

Abizadeh, Arash. 2002. Does Liberal Democracy Presuppose a Cultural Nation? Four Arguments. American Political Science Review 96(3): 495-509.

Ahdar, Rex and Ian Leigh. 2005. Religious Freedom in the Liberal State. Oxford: Oxford University Press.

Allievi, Stefano. 2009. Conflicts over Mosques in Europe: policy issues and trends. London: Alliance Publishing Trust.

Barry, Brian. 2001. Culture and Equality: An Egalitarian Critique of Multiculturalism. Cambridge: Polity. 
Bloom, Jonathan. 1989. Minaret: Symbol of Islam. Oxford: Oxford University Press.

Brownlie, Ian, and Guy Goodwin-Gill, eds. 2006. Basic Documents on Human Rights, $5^{\text {th }}$ edition. Oxford: Oxford University Press.

Canovan, Margaret. 1996. Nationhood and Political Theory. Cheltenham: Elgar.

Ceva, Emanuela and Federico Zuolo. Forthcoming. A Right to a Mosque? Access to Public Space, Religious Freedom and Participatory Goods. In Space and Pluralism, edited by Stefano Moroni and David Weberman. Budapest: CEU Press.

Dolezal, Martin, Marc Helbling and Swen Hutter. 2010. Debating Islam in Austria, Germany and Switzerland: Ethnic Citizenship, Church-State Relations and Right-Wing Populism. West European Politics 33(2): 171-90.

Eisenberg, Avigail. 2009. Reasons of Identity: A Normative Guide to the Political and Legal Assessment of Identity Claims. Oxford: Oxford University Press.

Evans, Caroline. 2001. Freedom of Religion under the European Convention on Human Rights. Oxford: Oxford University Press.

Fetzer, Joel and Christopher Soper. 2005. Muslims and the State in Britain, France and Germany. Cambridge: Cambridge University Press.

Freudiger, Patrick. ND. Kurz-Argumentarium zur Minarettverbots-Initiative. Available at http://www.minarette.ch/downloads/kurz-argumentarium minarettverbot.pdf, accessed $8^{\text {th }}$ November 2013.

Green, Todd. 2010. The Resistance to Minarets in Europe. Journal of Church and State 52(4): 619-643. 
Greenawalt, Kent. 2006. Religion and the Constitution, vol. 1: Free Exercise and Fairness.

Princeton and Oxford: Princeton University Press.

Habermas, Jurgen. 1998. The Inclusion of the Other, edited by Ciaran Cronin and Pablo de Greiff. Cambridge: Polity.

Hainmueller, Jens and Dominik Hangartner. 2013. Who Gets a Swiss Passport? A Natural Experiment in Immigrant Discrimination. American Political Science Review 107 (1): 159-87.

Helbling, Marc and Richard Traunmüller. 2014. How State Support of Religion Shapes Attitudes Towards Muslims.

Kelly, Paul (ed.). 2002. Multiculturalism Reconsidered. Cambridge: Polity.

Klausen, Jette. 2005. The Islamic Challenge: Politics and Religion in Western Europe. Oxford: Oxford University Press.

Kymlicka, Will. 1995. Multicultural Citizenship: a Liberal Theory of Minority Rights. Oxford: Clarendon Press.

Kymlicka, Will. 2001. Politics in the Vernacular: Nationalism, Multiculturalism and Citizenship. Oxford: Oxford University Press.

Laborde, Cécile. 2013. Political Liberalism and Religion: On Separation and Establishment. Journal of Political Philosophy 21(1): 67-86.

Linder, Wolf. 2010. Swiss Democracy: Possible Solutions to Conflict in Multicultural Societies, $3^{\text {rd }}$ edtion. Basingstoke: Palgrave Macmillan. 
Mason, Andrew. 2000. Community, Solidarity and Belonging. Cambridge: Cambridge University Press.

Miller, David. 1995. On Nationality. Oxford: Clarendon Press.

Miller, David. 2004. Justice, Democracy and Public Goods. Pp 127-49 in Justice and Democracy: Essays for Brian Barry, edited by Keith Dowding, Robert Goodin and Carol Pateman. Cambridge: Cambridge University Press.

Miller, David. 2007. National Responsibility and Global Justice. Oxford: Oxford University Press.

Miller, David. 2008. Immigrants, Nations and Citizenship. Journal of Political Philosophy 16 (4): 371-90.

Miller, David. 2012a. Grounding Human Rights. Critical Review of International Social and Political Philosophy, 15 (4): 407-27.

Miller, David. 2012b. Territorial Rights: Concept and Justification. Political Studies 60 (2): 252-68.

Miller, David. Forthcoming. Personhood versus Human Needs as Grounds for Human Rights. In Griffin on Human Rights, edited by Roger Crisp. Oxford: Oxford University Press.

Miller, David and Sundas Ali. Forthcoming. Testing the National Identity Argument. European Political Science Review.

Modood, Tariq. 2009. Muslims, religious equality and secularism. Pp. 164-185 in Secularism, Religion and Multicultural Citizenship, edited by Geoffrey Levey and Tariq Modood. Cambridge: Cambridge University Press. 
Nussbaum, Martha. 2008. Liberty of Conscience: In Defense of America's Tradition of Religious Equality. New York: Basic Books.

Nussbaum, Martha. 2012. The New Religious Intolerance: Overcoming the Politics of Fear in an Anxious Age. Cambridge, MA: Harvard University Press.

Patten, Alan. 2012. Liberal Neutrality: A Reinterpretation and Defense. Journal of Political Philosophy 20(3): 249-72.

Reimann, Lukas. 2009. Ein modernes Land hat keine Minarette. Neue Zürcher Zeitung, $20^{\text {th }}$ October. Available from http://www.nzz.ch/aktuell/startseite/ein-modernes-land-hat-keineminarette-1.3898699, accessed $8^{\text {th }}$ November 2013.

Tamir, Yael. 1993. Liberal Nationalism. Princeton: Princeton University Press.

Weinstock, Daniel. 2001. Prospects for Transnational Citizenship and Democracy. Ethics and International Affairs 15(2): 53-66.

Wimmer, Andreas. 2011. A Swiss Anomaly? A Relational Account of National Boundarymaking. Nations and Nationalism 17(4): 718-37. 